Jurnal Akuntansi dan Perpajakan, 5(2): 95-114, 2019

http://jurnal.unmer.ac.id/index.php/ap

\title{
Analisis Kinerja Keuangan Sebelum dan Setelah Akuisisi (Studi pada Perusahaan yang Terdaftar di BEI)
}

\author{
Anthalucky Dewi Andrian 1, Listyowati² \\ 1 Universitas Merdeka Malang, Jalan Terusan Raya Dieng no 62 - 64, Malang, 65146, Indonesia \\ 2 Universitas Merdeka Malang, Jalan Terusan Raya Dieng no 62 - 64, Malang, 65146, Indonesia
}

\begin{abstract}
The purpose of this research is to find out the difference of financial performance of the acquirer which is measured by using net profit margin, return on asset, return on equity, total assets turnover, debt to equity ratio, current ratio, dan earning per share before and after acquisition. The data used were secondary data obtained from websites the Indonesia Stock Exchange. With the population used is a company that performs the acquisition and is listed on the stock exchange Indonesia. The sample collection technique has been done by using purposive sampling, so 16 companies which has carried out the acquisition. The data analysis technique has been done by performing Paired Sample t-test. Based on the result of the analysis which has been carried out by using paired sample t-test that 5 financial ratios have significant difference i.e.: net profit margin, return on equity, return on assets, total assets turnover dan earning per share. that are 2 financial ratios which do not have any significant differences i.e. Debt to equity ratio, dan current ratio which means that there are no significant differences in these two ratios.

Keywords: Financial Performance; Financial Ratios; Acquisition
\end{abstract}

\section{ABSTRAK}

Tujuan penelitian adalah untuk mengetahui perbedaan kinerja keuangan pengakuisisi yang diukur dengan net profit margin, return on asset, return on equity, total assets turnover, debt to equity ratio, current ratio, dan earning per share antara sebelum dan setelah akuisisi. Data yang digunakan berupa data sekunder yang diperoleh dari website Bursa Efek Indonesia. Dengan populasi yang digunakan adalah perusahaan yang melakukan akuisisi dan terdaftar di Bursa Efek Indonesia. Teknik pengambilan sampel menggunakan metode purposive sampling, sehingga didapatkan sampel sebanyak 16 perusahaan yang melakukan aktivitas akuisisi pada periode 2013. Teknik analisis data yang digunakan dalam penelitian Teknik analisis data yang digunakan dalam penelitian adalah uji Paired Sample t-test. Berdasar hasil analisis dengan uji paired sample t-test terdapat 5 rasio keuangan yang mempunyai perbedaan secara signifikan yaitu net profit margin, return on equity, return on assets, total assets turnover dan earning per share. 2 rasio keuangan yang tidak mempunyai perbedaan secara signifikan yaitu Debt to equity ratio, dan current ratio.

Kata Kunci: kinerja keuangan; rasio keuangan; akuisisi

\section{PENDAHULUAN}

Berbagai strategi yang sering dilakukan perusahaan dalam meningkatkan kinerja perusahaan salah satunya adalah ekspansi. Ekspansi perusahaan dapat dilakukan baik dalam ekspansi internal maupun ekspansi eksternal. Ekspansi interna terjadi pada saat divisi-divisi yang ada dalam perusahaan tumbuh secara normal melalui capital budgeting. Sedangkan ekspansi eksternal dapat dilakukan dalam bentuk penggabungan usaha yang dapat berupa merger atau akuisisi.

Akuisisi merupakan penggabungan usaha dimana satu perusahaan, yaitu pengakuisisi memperoleh kendali atas aktiva bersih dan operasi perusahaan yang diakuisisi. Akuisisi sering dianggap sebagai investasi pada perusahaan anak yaitu suatu penguasaan mayoritas saham perusahaan lain sehingga tercipta hubungan perusahaan induk dan anak. Sedangkan merger merupakan penggabungan dua atau lebih perusahaan dimana satu perusahaan tetap hidup sedangkan perusahaan lainnya dilikuidasi. Dalam merger, perusahaan-perusahaan menggabungkan dan membagi sumber daya yang mereka miliki untuk mencapai tujuan bersama. Seluruh Harta dan kewajiban yang dimiliki perusahaan yang dilikuidasi diambil alih oleh perusahaan yang masih berdiri (Aprilita, 2013).

Alasan perusahaan lebih tertarik memilih strategi penggabungan usaha melalui akuisisi dan merger adalah karena dianggap sebagai jalan cepat untuk mewujudkan tujuan perusahaan dengan tidak memulai bisnis dari awal sehigga diharapkan dapat meningkatkan kinerja keuangan perusahaan. Alasan lain perusahaan melakukan akuisisi selain untuk pengembangan perusahaan adalah untuk mengembangkan kekayaan para pemegang saham guna menciptakan keunggulan kompetitif yang dapat diandalkan bagi 
perusahaan yang melakukan merger dan akuisisi (Aprilita, 2013).

Untuk menilai bagaimana keberhasilan akuisisi yang dilakukan, dapat dilihat dari kinerja perusahaan setelah melakukan akuisisi dan merger terutama kinerja keuangan perusahaan. Perubahan-perubahan setelah melakukan aktivitas akuisisi dan merger ini dapat tercermin dalam kondisi finansial perusahaan. Tetapi perubahan tersebut tidak bisa dilihat dalam waktu dekat melainkan dalam waktu jangka panjang. Jika kondisi finansial perusahaan setelah melakukan akuisisi menjadi lebih baik, maka keputusan akuisisi adalah tepat. Namun jika sebaliknya terjadi, maka keputusan melakukan akuisisi kurang tepat. Salah satu tolok ukur kinerja keuangan perusahaan adalah rasio keuangan. Sedangkan dilihat dari sisi investasi keberhasilan suatu perusahaan secara tidak langsung dapat diprediksi dari peningkatkan harga sahamnya di bursa saham. (Putri: 2013 : 2). Berdasarkan latar belakang tersebut, peneliti tertarik untuk membandingkan kinerja keuangan sebelum dan sesudah akuisisi pada perusahaan yang melakukan akuisisi dan merger yang terdaftar di BEI.

\section{Akuisisi}

Menurut IAI dalam PSAK No. 22 "Akuisisi (acqusition) adalah suatu penggabungan usaha dimana salah satu perusahaan, yaitu pengakuisisi (acquirer) memperoleh kendali atas aktiva netto dan operasi perusahaan yang diakuisisi (acquiree), dengan memberikan aktiva tertentu, mengakui suatu kewajiban, atau mengeluarkan saham".

Akuisisi adalah pengambilalihan kepemilikan atau pengendalian atas saham atau aset suatu perusahaan oleh perusaahaan lain, dan dalam peristiwa baik perusahaan pengambilalih atau yang diambil alih tetap eksis sebagai badan hukum yang terpisah. Akuisisi berbeda dengan merger karena akuisisi tidak menyebabkan pihak lain bubar sebagai entitas hukum (Rina, 2016).

Akuisisi berbeda dengan merger karena akuisisi tidak menyebabkan pihak lain bubar sebagai entitas hukum. Perusahaan-perusahaan yang terlibat dalam akuisisi secara yuridis masih tetap berdiri dan beroperasi secara independen tetapi telah terjadi pengalihan oleh pihak pengakusisi (Fairus, 2012). Akuisisi memunculkan hubungan antara perusahaan induk (pengakuisisi) dan perusahaan anak (terakuisisi) dan selanjutnya kedua memiliki hubungan afiliasi.

\section{Jenis-jenis Akuisisi}

Menurut Moin (2003) dalam Aprilita (2015:6) jenis akuisisi berdasarkan obyek yang diakuisisi dibedakan menjadi dua yaitu akuisi saham dan akuisisi aset.

\section{Akuisisi saham}

Digunakan untuk menggambarkan suatu transaksi jual beli perusahaan, dan transaksi tersebut mengakibatkan beralihnya kepemilikan perusahaan dari penjual kepada pembeli. Karena perusahaan didirikan atas saham-saham, maka akuisisi terjadi ketika pemilik saham menjual saham-saham mereka kepada pembeli/pengakuisisi.

\section{Akuisisi aset}

Apabila sebuah perusahaan bermaksud memiliki perusahaan lain maka la dapat membeli sebagian atau seluruh aktiva atau aset perusahaan lain tersebut. Jika pembelian tersebut hanya sebagian dari aktiva perusahaan maka hal ini dinamakan akuisisi parsial. Akuisisi aset dilakukan apabila pihak pengakuisisi tidak ingin terbebani hutang yang ditanggung oleh perusahaan target.

\section{Motif Akuisisi}

Pada prinsipnya terdapat beberapa motif yang mendorong sebuah perusahaan melakukan merger dan akuisisi (Aprilita, 2015:5), diantaranya motif ekonomi, motif sinergi, motif diversifikasi dan motif non ekonomi.

\section{Motif Ekonomi}

Motif ini dicapai dengan peningkatan nilai perusahaan setelah merger dan akuisisi. Motif ekonomi akuisisi meliputi mengurangi waktu, biaya dan risiko memasuki pasar baru, membangun kekuatan pasar, serta mengurangi persaingan. Esensi dari tujuan perusahaan, jika ditinjau dari perpektif manajemen keuangan, adalah seberapa besar perusahaan mampu menciptakan nilai (value creation) bagi perusahaan dan 
bagi pemegang saham. Akuisisi memiliki motif ekonomi yang tujuan jangka panjangnya adalah mencapai peningkatan nilai tersebut. Oleh karena itu seluruh aktivitas dan keputusan yang diambil oleh perusahaan harus diarahkan mencapai tujuan ini. Motif stategis juga termasuk motif ekonomi ketika aktivitas akuisisi dilakukan untuk mencapai posisi strategis perusahaan agar memberaikan keunggulan kompetitif bagi perusahaan. Implentasi program yang dilakukan oleh perusahaan harus melalui langkah-langkah konkrit misalnya melalui efisiensi produksi, peningkatan penjualan, pemberdayaan dan peningkatan produktivitas sumder daya manusia.

\section{Motif Sinergi}

Sinergi merupakan nilai keseluruhan perusahaan setelah akuisisi yang lebih besar dari pada penjumlahan nilai masing-masing perusahaan sebelum akuisisi. Sinergi dihasilkan melalui kombinasi aktivitas secara simultan dari kekuatan atau lebih elemen-elemen perusahaan yang bergabung sedemikian rupa sehingga gabungan aktivitas tersebut menghasilkan efek yang lebih besar dibandingkan dengan penjumlahan aktivitas-aktivitas perusahaan jika mereka bekerja sendiri. (Romapurnamasari, 2011:23).

Menurut Finansia (2017), terdapat beberapa sinergi yang mungkin didapatkan perusahaan yang bergabung adalah:

Sinergi operasi terjadi ketika perusahaan yang telah bergabung berhasil mencapai efisiensi biaya.

Sinergi finansial dihasilkan ketika perusahaan hasil merger memiliki struktur modal yang kuat dan mampu mengakses sumber-sumber dari luar secara lebih mudah dan murah sedemikian rupa sehingga biaya modal perusahaan semakin menurun. Perusahaan yang memiliki struktur permodalan kuat akan diberi penilaian positif oleh publik. Sinergi finansial juga dapat diperoleh dari perbaikan aliran kas.

Sinergi manajerial dihasilkan ketika terjadi transfer kapabilitas manajerial dan skill antar perusahaan. Sinergi teknologi dapat dicapai dengan memadukan keunggulan teknik sehingga perusahaanperusahaan merger dan akuisisi saling memetik manfaat.

Sinergi pemasaran ditunjukkan dengan semakin luas dan terbukanya pemasaran produk, bertambahnya lini produk yang dipasarkan, dan semakin banyaknya konsumen yang dapat dijangkau.

\section{Motif Diversifikasi}

Motif Diversifikasi dimaksud untuk mendukung aktivitas bisnis dan operasi perusahaan untuk mengamankan posisi bersaing. Manfaat lain diversifikasi adalah seperti transfer teknologi dan pengalokasian modal, sedangkan kerugian diversifikasi yaitu adanya subsidi silang (Finansia, 2017:31).

\section{Motif Non-ekonomi}

Aktivitas merger dan akuisisi terkadang dilakukan bukan untuk kepentingan ekonomi saja tetapi juga untuk kepentingan yang bersifat non-ekonomi, seperti prestise dan ambisi. Motif non-ekonomi bisa berasal dari manajemen perusahaan atau pemilik perusahaan (Finansia, 2017:31).

\section{Manfaat dan risiko Akuisisi}

Dalam banyak literature manajemen ditemukan bahwa dalam melakukan aktivitas akuisisi terdapat beberapa beberapa manfaat yang mungkin dihasilkan dari proses akuisisi antara lain: Meningkatkan efisiensi melalui sinergi yang tercipta diantara perusahaan yang dimerger atau diakuisisi; memperluas portfolio jasa yang ditawarkan yang akan berakibat pada bertambahnya sumber pendapatan bagi perusahaan; memperkuat daya saing perusahaan, dan lain sebagainya. Bagi perusahaan yang sedang berkembang, dengan membeli perusahaan lain memperoleh manfaat dimana akan lebih murah membeli aktiva perusahaan tersebut daripada membeli secara langsung.

Economic of scale dapat diperoleh dengan akuisisi horisontal, selain itu perusahaan akan memperoleh sinergi jika net income perusahaan gabungan lebih tinggi dari jumlah net income sebelum akuisisi. Pertumbuhan yang cepat sering lebih mudah dilaksanakan melalui penggabungan usaha daripada pertumbuhan internalnya. Pertimbangan lain adalah untuk diversifikasi produk yang dihasilkan dan untuk memperoleh tenaga yang profesional dengan cara membeli perusahaan lain. Namun selain manfaat yang mungkin dihasilkan, perlu juga diperhatikan kemungkinan risiko yang akan muncul sebagai hasil dari akuisisi, yaitu: seluruh kewajiban masing-masing perusahaan akan menjadi tanggungan perusahaan hasil merger atau akuisisi, termasuk kewajiban pembayaran dan penyerahan produk kepada vendor yang masih terhutang. 
Beban operasional, terutama dalam jangka pendek, akan semakin meningkat sebagai akibat dari proses penggabungan usaha. Perbedaan budaya (corporate culture), sistem dan prosedur yang diterapkan dimasing-masing perusahaan selama ini akan memerlukan penyesuaian dengan waktu yang relatif lama, dan sebagainya.

\section{Faktor Pemicu Keberhasilan dan Kegagalan Akuisisi}

Keberhasilan atau kegagalan suatu akuisisi sangat bergantung pada ketepatan analisis dan penelitian yang menyeluruh terhadap faktor-faktor penyelaras antara organisasi yang akan bergabung. Faktor-faktor yang dianggap memberi kontribusi terhadap keberhasilan akuisisi (Aprilita, 2013) yaitu: Melakukan audit sebelum akuisisi; Perusahaan target dalam keadaan baik; Memiliki pengalaman akusisi sebelumnya; Perusahaan target lebih kecil dan melakukan akuisisi yang bersahabat.

Adapun faktor-faktor yang memicu kegagalan akuisisi (Hitt, 2001 dalam Dewi, 2015) yaitu: Kesulitan integrasi; Utang banyak/ luar biasa; Ketidakmampuan mencapai sinergi; Manajer terlalu focus pada akuisisi dan terlalu besar.

\section{Kinerja Keuangan}

Dalam Kamus Besar Bahasa Indonesia (2001), Kinerja diartikan sebagai "sesuatu yang dicapai, prestasi yang diperlihatkan, kemampuan kerja (tentang peralatan)". Berdasarkan pengertian tersebut kinerja keuangan didefinisikan sebagai prestasi manajemen, dalam hal ini manajemen keuangan dalam mencapai tujuan perusahaan yaitu menghasilkan keuntungan dan meningkatkan nilai perusahaan. Analisis kinerja keuangan dalam penelitian ini bertujuan untuk menilai implementasi strategi perusahaan dalam hal merger dan akuisisi.

Pengertian kinerja keuangan adalah prestasi keuangan yang tergambar dalam laporan keuangan perusahaan yaitu neraca rugilaba dan kinerja keuangan menggambarkan usaha perusahaan (operation income). Profitability suatu perusahaan dapat diukur dengan menghubungkan keuntungan yang diperoleh dari kegiatan pokok perusahaan dengan kekayaan asset yang digunakan untuk menghasilkan keuntungan.

Pengukuran kinerja didefinisikan sebagai "performing measurement" (pengukuran kinerja) adalah kualifikasi dan efisiensi perusahaan atau segmen atau keefektifan dalam pengoperasian bisnis selama periode akuntansi. Pengertian kinerja adalah suatu usaha formal yang dilaksanakan perusahaan untuk mengevaluasi efisien dan efektivitas dari aktivitas perusahaan yang telah dilaksanakan pada periode waktu tertentu (Bayuristyawan, 2013). Menurut Sugiono (2009) dalam Fitriasari (2016) segi manajemen kuangan, perusahaan dikatakan mempunyai kinerja yang baik atau buruk dapat diukur dengan:

Kemampuan perusahaan untuk memenuhi kewajiban (utang) yang akan jatuh tempo (liquidity).

Kemampuan perusahaan untuk menyusun struktur pendanaan, yaitu perbandingan antara utang dan modal (leverage).

Kemampuan perusahaan memperoleh keuntungan (profitability).

Kemampuan perusahaan untuk berkembang (growth).

Kemampuan perusahaan untuk mengelola aset secara maksimal (activity).

\section{Analisis Laporan Keuangan}

Menurut Munawir (2010) dalam Finansia (2017), umumnya laporan keuangan terdiri dari neraca dan perhitungan laba-rugi serta laporan perubahan ekuitas. Neraca menggambarkan jumlah aset, kewajiban dan ekuitas dari suatu perusahaan pada tanggal tertentu. Sedangkan perhitungan (laporan) laba-rugi memperlihatkan hasil-hasil yang telah dicapai oleh perusahaan serta beban yang terjadi selama periode tertentu, dan laporan perubahan ekuitas menunjukkan sumber dan penggunaan atau alasan-alasan yang menyebabkan perubahan ekuitas perusahaan.

Berdasarkan sudut pandang investor, analisis laporan keuangan digunakan untuk memprediksi masa depan, sedangkan dari sudut pandang manajemen, analisis laporan keuangan digunakan untuk membantu mengantisipasi kondisi di masa depan dan, yang lebih penting, sebagai titik awal untuk perencananaan tindakan yang akan memengaruhi peristiwa di masa depan. Analisis rasio keuangan digunakan untuk mengetahui kinerja keuangan yang ingin dicapai perusahaan (Fitriasari, 2016). 
Tujuan analisis laporan keuangan secara lebih mendetail (Harahap, 2010 dalam Syafitri, 2016):

Dapat memberikan informasi yang lebih luas, lebih dalam daripada yang terdapat dari laporan keuangan biasa.

Dapat menggali informasi yang tidak tampak secara kasat mata dari suatu laporan keuangan atau yang berada di balik laporan.

Dapat mengetahui kesalahan yang terkandung dalam laporan keuangan.

Dapat memberikan informasi yang diinginkan oleh para pengambil keputusan.

Dapat membandingkan situasi perusahaan dengan perusahaan lain dengan periode sebelumnya.

Dapat memahami situasi dan kondisi keuangan yang dialami perusahaan, baik posisi keuangan, hasil usaha, struktur keuangan, dan sebagainya.

Dapat memprediksi potensi apa yang mungkin dialami perusahaan di masa yang akan datang.

\section{Alat Ukur Kinerja Keuangan}

Salah satu alat ukur yang biasa digunakan dalam menilai kineja keuangan adalah rasio keuangan. Analisis rasio keuangan merupakan metode umum yang digunakan untuk mengukur kinerja perusahaan di bidang keuangan. Rasio keuangan merupakan alat membandingkan angka-angka yang ada dalam laporan keuangan dengan cara membagi satu angka dengan angka lainnya. Perbandingan dapat dilakukan antara satu komponen dengan komponen dalam satu laporan keuangan atau antar komponen yang ada diantara laporan keuangan. Angka yang dapat diperbandingkan dapat berupa angka-angka dalam satu periode maupun beberapa periode. Sehingga dapat menunjukkan hubungan atau korelasi dari suatu laporan finansial berupa neraca dan laporan laba rugi (Syafitri, 2016).

Rasio keuangan merupakan kegiatan membandingkan angka-angka yang ada dalam laporan keuangan dengan cara membagi satu angka dengan angka lainnya. Perbandingan dapat dilakukan antara satu komponen dengan komponen dalam satu laporan keuangan atau antar komponen yang ada diantara laporan keuangan. Angka yang dapat diperbandingkan dapat berupa angka-angka dalam satu periode maupun beberapa periode (Kasmir, 2013 dalam Syafitri, 2016). Rasio keuangan yang digunakan pada penelitian ini adalah sebagai berikut:

\section{Rasio Profitabilitas}

Rasio profitabilitas adalah rasio yang digunakan untuk mengukur kemampuan suatu perusahaan dalam menghasilkan laba dengan menggunakan sumber-sumber yang dimiliki perusahaan, seperti aktiva, modal atau penjualan perusahaan. Rasio ini membantu perusahaan dalam mengontrol penerimaannya (Sudana, 2015:25). Adapun cara yang digunakan untuk mengukur besar kecilnya rasio profitabilitas dalam penelitian ini adalah:

\section{Net Profit Margin (NPM)}

Rasio Net Profit Margin ini mengukur seberapa besar kemampuan perusahaan dalam menghasilkan laba bersih operasional dari hasil penjualan yang dilakukan perusahaan. Rasio ini mencerminkan efisiensi seluruh bagian, yaitu produksi, personalia, pemasaran dan bagian keuangan yang ada dalam suatu perusahaan (Sudana, 2015:26). Untuk menghitung Net profit Margin dapat menggunakan rumus sebagai berikut (Sudana, 2015)

$N P M=\frac{\text { EarningAfterTax }}{\text { Sales }} \times 100 \%$

Meningkatnya profit margin mengindikasikan bahwa perusahaan mampu menghasilkan laba bersih yang lebih tinggi dari aktivitas penjualannya. Semakin tinggi tingkat profitabilitas maka semakin rendah tingkat likuiditas suatu perusahaan, yang dapat berdampak pada kegagalan perusahaan untuk melunasi kewajiban jangka pendek untuk (Mardiyanto, 2009).

Return on Equity (ROE)

Menurut Mardiyanto (2009) rasio ini mengukur keberhasilan perusahaan dalam menghasilkan laba bagi para pemegang saham. ROE dianggap sebagai representasi dari kekayaan pemegang saham atau nilai perusahaan. 
ROE $=\frac{E A T}{\text { TotalEkuitas }} \times 100 \%:$

Return On Assets (ROA)

Rasio ini menunjukan kemampuan perusahaan dengan menggunakan seluruh total aktiva yang dimiliki untuk menghasilkan laba setelah pajak. Rasio ini penting bagi pihak manajemen untuk mengevaluasi efektifitasdan efisiensi manajemen perusahaan dalam mengelolah seluruh aktiva perusahaan. Semakin tinggi ROA, menunjukan semakin efisien penggunaan aktiva perusahaan atau dengan kata lain dengan jumlah aktiva yang sama bisa dihasilkan laba yang besar dan juga sebaliknya (Sudana, 2015:25).

ROA $=\frac{E A T}{\text { TotalAssets }} \times 100 \%$

\section{Rasio Aktivitas}

Rasio aktivitas mengukur seberapa efektif manajemen perusahaan dalam mengelola aktiva yang dimiliki perusahaan. Dengan kata lain rasio ini mengukur seberapa besar kecepatan aset-aset perusahaan dikelola dalam rangka menjalankan bisnisnya (Sudana, 2015:24). Untuk menghitung rasio aktivitas peneliti menggunakan Total Assets Turnover (TATO).

TATO mengukur efektivitas penggunaan seluruh total aktiva dalam dalam menghasilkan penjualan. Semakin tinggi rasio ini menunjukan semakin efektif $p=$ pengelolaan seluruh aktiva yang dimiliki perusahaan. Rasio yang tinggi umumnya menunjukkan manajemen yang baik, sebaliknya rasio yang rendah maka manajemen harus mengevaluasi strategi, pemasaran, dan pengeluaran investasi atau modal (Sudana, 2015:25). Rumus rasio perputaran total aktiva yaitu,

$$
\text { TATO }=\frac{\text { Sales }}{\text { Total Aktiva }}
$$

\section{Rasio Solvabilitas}

Rasio solvabilitas adalah rasio yang menunjukkan kemampuan perusahaan dalam memenuhi segala kewajibannya baik jangka pendek maupun jangka panjang apabila perusahaan dilikuidasi (Sudana, 2015:23). Semakin besar rasio ini mencerminkan bahwa perusahaan memiliki kewajiban yang semakin besar. Variabel solvabilitas yang digunakan dalam penelitian ini adalah.Debt to Equity Ratio (DER).

Rasio hutang dengan modal sendiri atau debt to equity ratio yaitu imbangan antara hutang yang dimiliki perusahaan dengan modal sendiri. Semakin tinggi rasio ini artinya modal sendiri semakin sedikit dibanding dengan hutang. Bagi perusahaan sebaiknya, besar hutang tidak boleh melebihi modal sendiri agar beban tetap tidak terlalu tinggi. Semakin kecil rasio ini maka semakin baik. Maksudnya, semakin kecil porsi hutang terhadap modal, maka semakin aman. Rumus DER

$\mathrm{DER}=\frac{\text { I otal newajıoan }}{\text { Modal }} \mathrm{x} 100 \%$

\section{Rasio Likuiditas}

Rasio likuiditas merupakan kemampuan perusahaan untuk menyediakan alat-alat yang likuid, sehingga dapat memenuhi kewajiban finansial pada saat jatuh tempo, kewajiban itu sendiri bisa berkaitan dengan pihak intern maupun pihak ektern perusahaan (Fitriasari, 2015). Rasio likuiditas mengukur kemampuan perusahaan untuk memenuhi kemampuan kewajiban jangka pendek yang segera jatuh tempo (Sudana, 2015;24). Rasio likuiditas yang digunakan dalam penelitian ini adalah Current Ratio.

Current Ratio mengukur kemampuan perusahaan untuk membayar utang lancar perusahaan dengan menggunakan aktiva lancar yang dimiliki perusahaan. Semakin besar rasio ini menunjukan bahwa semakin likuid perusahaan. Rasio ini dihitung dengan membagi aset lancar dengan kewajiban lancar. Rasio ini menunjukkan sampai sejauh apa kewajiban lancar ditutupi oleh aset yang diharapkan akan dikonversi menjadi kas dalam waktu dekat (Sudana, 2015:24).

\footnotetext{
$\frac{\text { Aset Lancar }}{\text { Kewajban Lancar }} \times 100 \%$
} 
Current ratio yang tinggi mungkin menunjukkan adanya uang kas yang berlebihan dibanding dengan tingkat kebutuhan atau adanya unsur aktiva lancar yang rendah likuiditasnya (seperti persediaan) yang berlebih-lebihan.

\section{Rasio Pasar}

Rasio pasar mengukur seberapa besar nilai pasar saham perusahaan dibanding dengan nilai buku. Lebih dari itu rasio ini mengukur bagaimana nilai perusahaan saat ini dan dimasa yang akan dating dibandingkan dengan nilai perusahaan di masa lalu. Earning Per Share (EPS). Rumus Earning Per Share

EPS $=\frac{\text { Laba bersih setelah pajak }}{\text { Jumlah saham biasa yang beredar }}$

\section{METODE}

Definisi Operasional Variabel

Penelitian ini menganalisis secara empiris tentang pengukuran kinerja keuangan perusahaan sebelum dan sesudah akuisisi dan merger. Pada dasarnya variabel dalam penelitian ini adalah kinerja keuangan perusahaan yang melakukan akuisisi. Kinerja keuangan perusahaan diukur dengan indikator rasio keuangan, yaitu :

\section{Net Profit Margin (NPM)}

Net Profit margin dalam penelitian ini diukur dengan menggunakan rata-rata net profit margin sebelum dan sesudah akuisisi. Rasio ini merupakan kemampuan perusahaan dalam menghasilkan laba bersih yang dapat dihasilkan dari penjualan atau pendapatan.

$N P M=\frac{\text { Laba bersih }}{\text { Penjualan Bersih }} \times 100 \%$

\section{Return On Equiity (ROE)}

Return On Equiity dalam penelitian ini diukur dengan menggunakan rata-rata Return On Equiity sebelum dan sesudah akuisisi. Rasio ini memperlihatkan sejauh manakah perusahaan mengelola modal sendiri secara efektif, mengukur tingkat keuntungan dari investasi yang dilakukan pemilik modal sendiri atau pemegang saham.

ROE $=\frac{\text { EAT }}{\text { Total Ekuitas }} \times 100 \%$

\section{Return On Assets (ROA)}

Return On Assets dalam penelitian ini diukur dengan menggunakan rata-rata Return On Assets sebelum dan sesudah akuisisi. Rasio ini menunjukan kemampuan perusahaan dengan menggunakan seluruh total aktiva yang dimiliki untuk menghasilkan laba bersih.

ROA $=\frac{\text { EAT }}{\text { Total Assets }} \times 100 \%$

Total Assets Turn Over (TATO)

Total Assets Turn Over dalam penelitian ini diukur dengan menggunakan rata-rata Total Assets Turn Over sebelum dan sesudah akuisisi. Rasio ini Mengukur seberapa efektif penggunaan seluruh aktiva di dalam perusahaan untuk menghasilkan penjualan tertentu dalam periode tertentu ( 1 tahun).

$$
\text { TATO }=\frac{\text { Penjualan }}{\text { Total Aktiva }}
$$

\section{Debt to Equity Ratio (DER)}

Debt to Equity Ratio dalam penelitian ini diukur dengan menggunakan rata-rata Debt to Equity Ratio sebelum dan sesudah akuisisi. Rasio ini menunjukkan perbandingan antara utang dengan modal sendiri. 
$\mathrm{DER}=\frac{\text { Total Kewajiban }}{\text { Modal }} \times 100 \%$

Current Ratio (CR)

Current Ratio dalam penelitian ini diukur dengan menggunakan rata-rata Current Ratio sebelum dan sesudah akuisisi. Rasio ini menunjukkan tingkat keamanan jangka pendek atau kemampuan perusahaan membayar hutang lancarnya dengan menggunakan aktiva lancar.

$\mathrm{CR}=\frac{\text { Aset Lancar }}{\text { Kewajiban Lancar }} \times 100 \%$

Earning Per Share (EPS)

Earning Per Share dalam penelitian ini diukur dengan menggunakan rata-rata Erning Per Share sebelum dan sesudah akuisisi. Rasio ini menunjukan seberapa besar kemampuan per lembar saham dalam menghasilkan laba.

EPS $=\frac{E A T}{\text { Jumlah saham biasa yang beredar }}$

Penelitian ini dilakukan pada perusahaan-perusahaan yang melakukan akuisisi yang terdaftar di Bursa Efek Indonesia dengan website www.idx.co,id. Sampel penelitian diambil setelah memenuhi beberapa kriteria yang berlaku bagi penerapan definisi operasional variabel. Teknik pengambilan sampel diambil dengan teknik purposive sampling yaitu pemilihan pengambilan sampel dengan berdasarkan pada kriteriakriteria tertentu. Adapun kriteria-kriteria yang digunakan dalam penelitian ini mencakup:

Perusahaan publik yang terdaftar di Bursa Efek Indonesia dan melakukan akuisisi di tahun 2013.

Perusahaan memiliki tanggal akuisisi yang jelas.

Menerbitkan laporan keuangan secara lengkap selama tiga tahun sebelum akuisisi serta tiga tahun sesudah akuisisi dengan periode berakhir per 31 Desember.

Sumber data yang digunakan dalam penelitian ini adalah data sekunder. Jenis data yang digunakan untuk penelitian ini adalah data kuantitatif berupa laporan keuangan perusahaan yang digunakan untuk menganalisis kinerja keuangan perusahaan. Teknik pengumpulan data yang digunakan dalam penelitian inii adalah dengan metode dokumentasi, yaitu dengan mengumpulkan data laporan keuangan perusahaan yang diperoleh melalui website perusahaan atau situs resmi BEI (www.idx.co.id), serta menghitung kinerja keuangan dengan menggunakan rasio keuangan. Serta mempelajari literatur yang berkaitan dengan permasalahan penelitian ini baik dari jurnal penelitian, skripsi maupun buku-buku teks yang berupa media cetak maupun elektronik.

Dalam penelitian ini, analisa data yang digunakan adalah data yang berisfat kuantitatif, yaitu data yang didapatkan dari hasil perhitungan tertentu dan terdiri dari angka-angka terhadap masalah yang diteliti. Dalam menganalisis data, penelitian ini menggunakan beberapa uji statistik. Uji statistik yang digunakan dalam penelitian ini adalah untuk menguji hipotesis.

\section{HASIL}

Sampel Penelitian

Penelitian ini dilakukan pada peusahaan yang melakukan akuisisi yang listing di Bursa Efek Indonesia (BEI) untuk periode 2013. Penelitian ini menggunakan data sekunder yang berupa laporan keuangan perusahaan yang terdaftar di BEI melalui website resmi BEI (www.idx.co.id). Dalam penelitian ini, metode pengambilan sampel yang digunakan peneliti adalah metode purposive sampling.

Tabel 1. Teknik Penarikan Sampel

\begin{tabular}{|c|l|c|}
\hline No & \multicolumn{1}{|c|}{ Keterangan } & Jumlah \\
\hline 1 & $\begin{array}{l}\text { Perusahaan yang melakukan aktivitas akuisisi 2013 yang ter- } \\
\text { daftar di Bursa Efek Indonesia. }\end{array}$ & 48 \\
\hline 2 & $\begin{array}{l}\text { Terdapat laporan keuangan tiga tahun sebelum dan sesudah } \\
\text { akuisisi. }\end{array}$ & 16 \\
\hline 3 & Perusahaan yang memenuhi sampel penelitian. & 16 \\
\hline
\end{tabular}

Sumber: www.idx.co.od, data diolah (2018). 
Berdasarkan kriteria di atas maka dalam penelitian ini diperoleh sebanyak 16 perusahaan yang melakukan akuisisi yang dipakai sebagai sampel penelitian. Daftar nama perusahaan yang menjadi sampel sebagai berikut:

Tabel 2. Daftar Perusahaan Sampel

\begin{tabular}{|c|c|l|}
\hline No & Kode & \multicolumn{1}{c|}{ Nama Perusahaan } \\
\hline 1 & AKRA & PT Anugrah Karya Raya \\
\hline 2 & MEDC & PT Medco Power Indonesia \\
\hline 3 & AISA & Tiga Pilar Sejahtera Food \\
\hline 4 & SGRO & Samporna Agro Tbk \\
\hline 5 & AUTO & PT Astra Otoparts Tbk \\
\hline 6 & ADRO & PT Alam Tri Abadi \\
\hline 7 & HRUM & PT Harum Energy Tbk \\
\hline 8 & TKIM & PT Pabrik Kertas Tjiwi Kimia Tbk \\
\hline 9 & INDS & PT Indospring tbk \\
\hline 10 & ICBP & PT Asahi Indofood Beverage Makmur \\
\hline 11 & SMRA & Summarecon Agung \\
\hline 12 & INDF & PT Indofood Asahi Sukses Beverag \\
\hline 13 & APLN & PT Agung Podomoro Land, Tbk \\
\hline 14 & TLKM & PT Telekomunikasi Indonesia \\
\hline 15 & DPNS & PT Duta Pertiwi Nusantara Tbk \\
\hline 16 & SMGR & PT Semen Indonesia Tb \\
\hline
\end{tabular}

Sumber: data diolah (2018)

Analisis Deskriptif

Analisis deskriptif digunakan untuk memberikan gambaran atau informasi tentang kondisi variabelvariabel yang digunakan dalam penelitian. Pengukuran yang digunakan dalam penlitian ini menggunakan rata-rata variabel perusahaan sampel sebelum dan sesudah akuisisi. Adapun hasil perhitungan statistik deskriptif variabel penelitian selama 3 tahun sebelum dan sesudah akuisisi dengan menggunakan SPSS 24 disajikan dalam tabel 3 berikut: 
Tabel 3. Statistik Deskriptif Variabel Penelitian selama 3 tahun sebelum dan sesudah akuisisi

\begin{tabular}{|c|c|c|c|c|c|c|c|c|c|c|c|c|c|c|}
\hline & \multicolumn{2}{|c|}{ NPM } & \multicolumn{2}{|c|}{ ROE } & \multicolumn{2}{|c|}{ ROA } & \multicolumn{2}{|c|}{ TATO } & \multicolumn{2}{|c|}{ DER } & \multicolumn{2}{|c|}{ CR } & \multicolumn{2}{|c|}{ EPS } \\
\hline & Sebelum & Sesudah & Sebelum & Sesudah & Sebelum & Sesudah & Sebelum & Sesudah & Sebelum & Sesudah & Sebelum & Sesudah & Sebelum & Sesudah \\
\hline AKRA & 5,93 & 3,88 & 30,93 & 13,09 & 12,39 & 5,51 & 1,90 & 1,45 & 171,28 & 143,21 & 128,24 & 125,12 & 280,10 & 209,48 \\
\hline MEDC & 7,77 & $-7,01$ & 8,05 & $-5,43$ & 2,71 & $-1,10$ & 0,35 & 0,29 & 139,34 & 224,90 & 209,87 & 186,44 & 20,40 & $-10,01$ \\
\hline AISA & 6,01 & 7,37 & 6,98 & 11,56 & 4,96 & 5,39 & 0,52 & 0,72 & 138,12 & 115,70 & 148,27 & 201,21 & 74,09 & 120,20 \\
\hline SGRO & 16,18 & 8,01 & 18,59 & 7,85 & 15,67 & 4,19 & 0,93 & 0,52 & 41,60 & 87,30 & 153,00 & 104,08 & 236,88 & 129,10 \\
\hline AUTO & 15,64 & 6,63 & 24,53 & 7,74 & 16,35 & 5,64 & 1,04 & 0,84 & 49,26 & 38,56 & 141,60 & 149,82 & 292,09 & 162,00 \\
\hline ADRO & 11,04 & 6,04 & 15,78 & 5,77 & 6,98 & 2,93 & 0,62 & 0,49 & 124,48 & 95,08 & 166,61 & 196,81 & 113,90 & 74,77 \\
\hline HRUM & 24,25 & $-0,38$ & 50,87 & 2,58 & 42,06 & 5,53 & 1,77 & 1,76 & 32,17 & 18,40 & 263,24 & 464,77 & 631,19 & 44,58 \\
\hline TKIM & 3,34 & 1,88 & 6,36 & 2,43 & 1,84 & 0,81 & 0,53 & 0,44 & 245,83 & 203,55 & 207,58 & 185,07 & 33,78 & 10,85 \\
\hline INDS & 9,17 & 3,33 & 13,09 & 3,16 & 8,45 & 2,56 & 0,92 & 0,71 & 34,42 & 6,85 & 286,46 & 272,54 & 420,11 & 91,00 \\
\hline ICBP & 10,05 & 9,39 & 18,52 & 18,06 & 12,16 & 11,24 & 1,21 & 1,20 & 50,51 & 61,17 & 268,14 & 230,53 & 376,37 & 332,07 \\
\hline SMRA & 22,04 & 11,86 & 19,99 & 8,80 & 6,76 & 3,57 & 0,31 & 0,32 & 201,76 & 153,54 & 127,34 & 169,49 & 82,19 & 45,29 \\
\hline INDF & 8,84 & 7,30 & 12,93 & 11,19 & 7,26 & 5,51 & 0,81 & 0,75 & 82,33 & 104,04 & 187,44 & 167,63 & 501,63 & 539,30 \\
\hline APLN & 18,28 & 17,64 & 13,25 & 11,12 & 5,53 & 4,12 & 0,30 & 0,23 & 142,54 & 169,52 & 169,11 & 142,98 & 39,94 & 51,26 \\
\hline TLKM & 23,26 & 23,91 & 26,34 & 25,83 & 15,79 & 15,16 & 0,68 & 0,63 & 55,97 & 69,47 & 109,38 & 120,49 & 652,33 & 250,92 \\
\hline DPNS & 12,00 & 7,45 & 12,69 & 4,68 & 11,12 & 4,12 & 0,91 & 0,61 & 21,57 & 13,38 & 797,96 & 1358,09 & 81,32 & 34,62 \\
\hline SMGR & 23,72 & 18,27 & 26,26 & 17,87 & 18,69 & 12,79 & 0,79 & 0,69 & 40,69 & 40,31 & 207,83 & 169,28 & 800,23 & 822,39 \\
\hline Rata-rata & 13,59 & 7,85 & 19,07 & 9,14 & 11,79 & 5,50 & 0,85 & 0,73 & 98,24 & 96,56 & 223,25 & 265,27 & 289,78 & 181,74 \\
\hline
\end{tabular}

Sumber: data diolah (2018)

Pada hasil perhitungan tabel 3, menggambarkan kondisi perusahaan yang melakukan akuisisi selama periode 3 tahun sebelum dan sesudah melakukan akuisisi, dilihat dari beberapa rasio yaitu:

\section{Net Profit Margin (NPM)}

Pada hasil perhitungan pada tabel diatas, terlihat bahwa perubahan nilai rata-rata Net Profit Margin sebelum akuisisi sebesar 13,59\% sedangkan setelah melakukan akuisisi sebesar 7,85\%, sehingga perubahan rata-rata seluruh sampel menunjukkan adanya penurunan setelah melakukan akuisisi, yaitu sebesar $42 \%$. Penurunan yang terjadi pada NPM menunjukkan bahwa akuisisi yang dilakukan oleh perusahaan menyebabkan menurunnya jumlah penjualan yang di lakukan setelah melakukan akuisisi. Sehingga saat sesudah melakukan akuisisi, perusahaan belum mampu meningkatkan laba bersih perusahaan dari hasil penjualan/pendapatan perusahaan.

Dilihat dari rata-rata NPM sebelum melakukan akuisis, nilai rata-rata NPM terendah terjadi pada TKIM yaitu sebesar 3,34\%, dan nilai rata-rata NPM tertinggi terjadi pada SMGR yaitu sebesar 23,72\%. Sedangkan rata-rata tertinggi setelah melakukan akuisisi terjadi pada MEDC yaitu sebesar -7,01\%, sedangka rata-rata tertinggi terjadi pada TKIM yaitu sebesar 23,91\%.

\section{Return On Equity (ROE)}

Pada hasil perhitungan pada tabel diatas, terlihat bahwa perubahan nilai rata-rata ROE seluruh sampel menunjukkan adanya penurunan yang sangat besar setelah melakukan akuisisi, yaitu sebesar $52 \%$. Penurunan yang terjadi pada nilai rata-rata ROE, menunjukan tingkat profitabilitas cenderung menurun, dengan kata lain kemampuan perusahaan dalam menghasilkan laba bagi para pemegang saham setelah melakukan akuisisi menurun. Hal ini dikarenakan perusahaan cenderung memiliki ekuitas yang besar, karena adanya aktivitas akuisisi dan merger.

Dilihat dari rata-rata ROE sebelum melakukan akuisis, nilai rata-rata ROE terendah terjadi pada TKIM yaitu sebesar 6,36\%, dan nilai rata-rata ROE tertinggi terjadi pada HRUM yaitu sebesar 50,87\%. Sedangkan rata-rata terendah setelah melakukan akuisisi terjadi pada MEDC yaitu sebesar -5,46\%, dan untuk nilai rata-rata tertinggi terjadi pada TKIM yaitu sebesar 25,83\%.

Return On Assets (ROA)

Pada hasil perhitungan pada tabel diatas, terlihat bahwa perubahan nilai rata-rata ROA seluruh sampel menunjukkan adanya penurunan yang sangat besar setelah melakukan akuisisi. Penurunan yang terjadi mengindikasikan bahwa kemampuan perusahaan dalam meningkatkan jumlah laba bersih perusahaan 
Jurnal Akuntansi \& Perpajakan

Vol. 5 (2) 2019: 95-114

dengan mengalokasikan aktiva perusahaan, setelah melakukan akuisisi kurang begitu efektif.

Dilihat dari rata-rata ROA sebelum melakukan akuisis, nilai rata-rata ROE terendah terjadi pada TKIM yaitu sebesar $-1,84 \%$, dan nilai rata-rata ROE tertinggi terjadi pada HRUM yaitu sebesar $42,06 \%$. Sedangkan rata-rata terendah setelah melakukan akuisisi dan merger terjadi pada MEDC yaitu sebesar $1,10 \%$ dan untuk nilai rata-rata tertinggi terjadi pada TKIM yaitu sebesar 15,16\%.

\section{Total Assets Turn Over (TATO)}

Pada hasil perhitungan pada tabel diatas, terlihat bahwa perubahan nilai rata-rata TATO seluruh sampel menunjukkan adanya penurunan yang sangat besar setelah melakukan akuisisi. Penurunan nilai TATO disebabkan menurunnya jumlah penjualan perusahaan dari total aktiva sesudah melakukan akuisisi. Menurunnya nilai TATO menunjukkan bahwa kurang efektifnya perusahaan menggunakan seluruh aktiva yang dimiliki perusahaan untuk menghasilkan penjualan yang lebih besar.

Dilihat dari rata-rata TATO sebelum melakukan akuisis, nilai rata-rata TATO terendah terjadi pada APLN yaitu sebesar 0,30 kali, dan nilai rata-rata TATO tertinggi terjadi pada HRUM yaitu sebesar 42,06 kali. Sedangkan rata-rata terendah setelah melakukan akuisisi terjadi pada MEDC yaitu sebesar -1,10 kali dan untuk nilai rata-rata tertinggi terjadi pada HRUM yaitu sebesar 1,76 kali.

\section{Debt to Equity Ratio (DER)}

Pada hasil perhitungan pada tabel diatas, terlihat bahwa perubahan nilai rata-rata DER seluruh sampel menunjukkan adanya penurunan yang sangat besar setelah melakukan akuisisi. Penurunan nilai DER disebabkan menurunnya jumlah kewajiban perusahaan setelah melakukan akuisisi. Hal ini mengindikasikan bahwa perusahaan cukup bisa dikatakan mampu untuk membayar hutang yang dimiliki perusahaan dan mampu untuk memaksimalkan modal sendiri. Berarti modal sendiri sudah cukup untuk menjamin atau melunasi hutang perusahaan karena ekuitas perusahaan lebih tinggi dari pada hutang perusahaan.

Dilihat dari rata-rata DER sebelum melakukan akuisis dan merger, nilai rata-rata DER terendah terjadi pada DPNS yaitu sebesar 21,37\%, dan nilai rata-rata ROE tertinggi terjadi pada TKIM yaitu sebesar $245,83 \%$. Sedangkan rata-rata terendah setelah melakukan akuisisi dan merger terjadi pada INDS yaitu sebesar 6,85\% dan untuk nilai rata-rata tertinggi terjadi pada MEDC yaitu sebesar 224,90\%.

\section{Current Ratio (CR)}

Pada hasil perhitungan pada tabel diatas, terlihat bahwa perubahan nilai rata-rata CR seluruh sampel menunjukkan adanya peningkatan setelah melakukan akuisisi. Peningkatan yang terjadi pada CR menunjukkan bahwa akuisisi yang dilakukan oleh perusahaan menyebabkan aktiva lancar yang lebih besar dari jumlah utang lancar. Sehingga kemampuan perusahaan meningkat dalam menjaga likuiditas perusahaanya dan perusahaan mampu menjamin kewajiban jangka pendek perusahaan setelah melakukan akuisisi dan merger dengan aktiva lancar yang dimiliki.

Dilihat dari rata-rata CR sebelum melakukan akuisis, nilai ratarata CR terendah terjadi pada TKIIM yaitu sebesar 109,38\%, dan nilai rata-rata CR tertinggi terjadi pada DPNS yaitu sebesar 797,96\%. Sedangkan rata-rata terendah setelah melakukan akuisisi terjadi pada INDS yaitu sebesar 104,08\% dan untuk nilai rata-rata tertinggi terjadi pada DPNS yaitu sebesar $1358,09 \%$.

\section{Earning Per Share (EPS)}

Pada hasil perhitungan pada tabel diatas, terlihat bahwa perubahan nilai rata-rata EPS seluruh sampel menunjukkan adanya penurunan yang sangat setelah melakukan akuisisi. Penurunan yang terjadi ini diakarenakan setelah perusahaan melakukan akuisisi, terjadi penurunan pada laba yang dibagikan ke pemegang saham. Penurunan ini dikarenakan pada saat setelah melakukan akuisisi, perusahaan masih menggunakan biaya yang besar untuk membiayai kegiatan setelah aktivitas akuisisi, sehingga menyebabkan laba yang menurun.

Dilihat dari rata-rata EPS sebelum melakukan akuisis dan merger, nilai rata-rata EPS terendah terjadi pada SMGR yaitu sebesar 20,40 kali, dan nilai rata-rata EPS tertinggi terjadi pada DPNS yaitu sebesar 800,23 kali. Sedangkan rata-rata terendah setelah melakukan akuisisi dan merger terjadi pada MEDC yaitu sebesar 10,01 kali dan untuk nilai rata-rata tertinggi terjadi pada SMGR yaitu sebesar 822,39 kali. 
Pengujian Hipotesis

Berdasarkan hasil analisis yang dilakukkan oleh peneliti yang di gunakan untuk menjawab hasil pengujian perbedaan antara dua sample yang berpasangan atau berhubungan. Penelitian ini mengajukan 7 buah hipotesis dengan 16 perusahaan sampel. Uji statistik yang digunakan adalah uji paired sample t-test. Kriteria pengujian dilakukan menggunakan tingkat keyakinan 95\% dengan tingkat signifikansi 5\% atau nilai probabilitas significance (2-tailed) $<0,05$. Berikut ini merupakan ringkasan hasil pengujian dari masing-masing hipotesis

Tabel 4. Ringkasan Hasil Uji Paired Sample T-Test

\begin{tabular}{|l|c|c|l|}
\hline \multicolumn{1}{|c|}{ Variabel } & \multicolumn{1}{c|}{$\mathrm{t}$} & Sig. (2-tailed) & Kesimpulan \\
\hline NPM_Sebelum - NPM_Sesudah & 3,441 & 0,004 & Ha.1 diterima \\
\hline ROE_Sebelum - ROE_Sesudah & 3,313 & 0,005 & Ha.2 diterima \\
\hline ROA_Sebelum - ROA_Sesudah & 2,863 & 0,012 & Ha.3 diterima \\
\hline TATO_Sebelum - TATO_Sesudah & 2,972 & 0,009 & Ha.4 diterima \\
\hline DER_Sebelum - DER_Sesudah & 0,193 & 0,850 & Ha.5 ditolak \\
\hline CR_Sebelum - CR_Sesudah & $-1,117$ & 0,281 & Ha.6 ditolak \\
\hline EPS_Sebelum - EPS_Sesudah & 2,434 & 0,028 & Ha.7 diterima \\
\hline
\end{tabular}

Sumber: Hasil olah SPSS 24 (2018)

\section{PEMBAHASAN}

Net Profit Margin (NPM) sebelum dan sesudah akuisisi.

Hasil penelitian ini mendukung hipotesis pertama yaitu net profit berbeda secara signifikan antara sebelum dan sesudah akuisisi. Data tersebut menunjukkan bahwa terdapat perbedaan signifikan pada Net Profit Margin sebelum dan setelah akuisisi dan merger. Maka hipotesis alternatif pertama (Ha.1) dalam penelitian ini diterima.

Aktivitas merger dan akuisisi tidak membuat kemampuan perusahaan dalam memperoleh laba meningkat. Rata-rata Net Profit Margin relatif mengalami penurunan secara signifikan setelah melakukan akuisisi, ditunjukkan dengan rata-rata Net Profit Margin sebelum akuisisi sebesar 13,59\% sedangkan setelah melakukan akuisisi sebesar 7,85\%, sehingga perubahan penurunan rata-rata Net Profit Margin setelah akuisisi sekitar 42\%. Manajemen perusahaan kurang mengoptimalkan penjualan untuk peningkatan laba perusahaan Laba bersih yang diperoleh perusahaan mengalami perubahan yang signifikan setelah akuisisi, mengindikasikan kurangnya perusahaan dalam memperoleh keuntungan berdasarkan hasil penjualan perusahaan.

Penurunan Net Profit Margin setelah melakukan akuisisi dikarenakan pada saat sesudah perusahaan melakukan akuisisi, biaya-biaya dikeluarkan perusahaan cukup besar untuk membiayai perusahaan yang diambil alih sehingga menyebabkan laba yang dihasilkan mengalami penurunan. Seperti penurunan Net Profit Margin yang terjadi pada SMGR, dengan penjualan yang tinggi menghasilkan laba yang rendah. Dengan jumlah penghasilan yang dimiliki oleh SMGR pada saat sebelum akuisisi. 
Jurnal Akuntansi \& Perpajakan

Vol. 5 (2) 2019: 95-114

\begin{tabular}{|c|c|c|c|c|}
\hline & 2014 & Notes & 2013 & \\
\hline PENDAPATAN & 26.987 .035 .135 & 32 & 24.501 .240 .780 & REVENUE \\
\hline BEBAN POKOK PENDAPATAN & $(15.388 .431 .050)$ & 33 & $(13.557 .146 .834)$ & COST OF REVENUE \\
\hline LABA BRUTO & 11.598 .604 .085 & & 10.944 .093 .946 & GROSS PROFIT \\
\hline Beban perjualan & $(2.692 .902 .707)$ & 34 & (2.283.452.142) & Seling expenses \\
\hline $\begin{array}{l}\text { Beban umum dan administrasi } \\
\text { Penghasilan operasi lainnya } \\
\text { Pendapatan keuangan }\end{array}$ & $\begin{array}{c}(1.951 .961 .379) \\
201.928 .038 \\
286.070 .140\end{array}$ & $\begin{array}{l}35 \\
36 \\
37\end{array}$ & $\begin{array}{r}(1.688 .256 .993) \\
90.608 .036 \\
163.033 .492\end{array}$ & $\begin{array}{l}\text { General and administrason expenses } \\
\text { Other operabing income } \\
\text { Finance income }\end{array}$ \\
\hline Beban keuangan & (382.919.122) & 37 & $(340.168 .567)$ & Finance costs \\
\hline Bagian laba bersih entyas asosiasi & 31.946 .912 & 13 & 34.541 .962 & Net equity income in associates \\
\hline LABA SEBELUM PAJAK PENGHASILAN & 7.090 .765 .967 & & 6.920 .399 .734 & PROFIT BEFORE INCOME TAX \\
\hline Beban pajak penghasilan & $(1.517 .188 .688)$ & 39 & $(1.566 .101 .213)$ & hcome tax expense \\
\hline LABA BERSIH TAHUN BERJALAN & 5.573 .577 .279 & & 5.354 .298 .521 & NET PROFIT FOR THE YEAR \\
\hline
\end{tabular}

Gambar 1. Ringkasan Laporan Keuangan P.T. Semen Indonesia, Tbk.

Sumber: www.idx.co.id (2018)

Dari tabel diatas menunjukan bahwa laba bersih yang dihasilkan oleh SMGR mengalami penurunaan namun pendapatan yang dihasilkan oleh SMGR mengalami peningkatan. Penurunan Laba bersih ini dikarenakan laba operasional yang dikeluarkan perusahaan mengalami peningkatan. Sehingga, dapat disimpulkan bahwa terdapat perbedaan yang signifikan pada Net Profit Margin sebelum dan sesudah aktivitas akuisisi dan merger. Hasil penelitian ini konsisten dengan hasil penelitian yang dilakukan oleh Aprilia (2015) dimana hasil penelitiannya adalah terdapat perbedaan secara signifikan pada Net Profit Margin sesudah akuisis.

Return On Equity (ROE) Sebelum dan sesudah akuisisi

Hasil penelitian ini mendukung hipotesis kedua yaitu Return On Equity berbeda secara signifikan antara sebelum dan sesudah akuisisi. Data tersebut menunjukkan bahwa terdapat perbedaan signifikan pada Return on Equity sebelum dan setelah akuisisi. Maka hipotesis alternatif pertama (Ha.2) dalam penelitian ini diterima.

Aktivitas akuisisi tidak membuat kemampuan perusahaan dalam memperoleh laba meningkat. Ratarata return on equity yang relatif mengalami penurunan setelah melakukan aktivitas akuisisi menunjukkan bahwa penggabungan total ekuitas perusahaan yang bergabung tidak mampu meningkatkan perolehan laba perusahaan secara signifikan. Penurunan tersebut ditunjukkan dengan rata-rata ROE sebelum akuisisi sebesar $19,07 \%$, dan pada saat setelah akuisisi menjadi $9,14 \%$, sehingga perubahan penurunan rata-rata Return On Equity setelah akuisisi sekitar 52\%. Sebagai salah satu contoh perusahaan sampel yaitu AKRA. Ekuitas yang dimiliki AKRA pada saat setelah melakukan akuisisi mengalami peningkatan, tetapi disisi laba rugi yaitu laba bersih justru mengalami penurunan sehingga menyebabkan Return On Equity cenderung menurun. Berikut adalah ringkasan laporan keuangan yang dimiliki AKRA. 


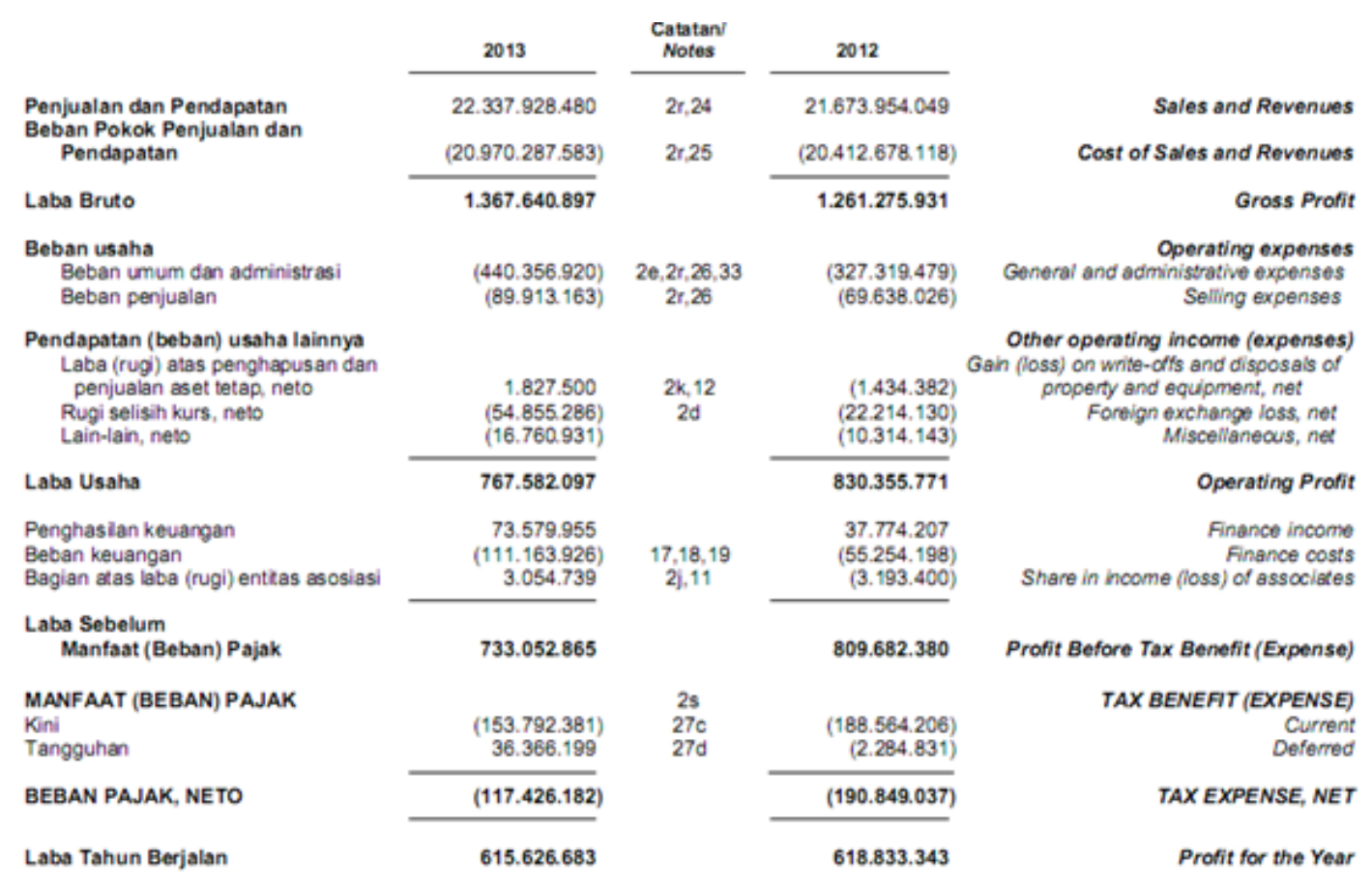

Gambar 2. Ringkasan Keuangan P.T. Anugrah Karya Raya

Sumber: www.idx.co.id (2018)

Terlihat pada gambar di atas bahwa Laba tahun berjalan yang dimiliki AKRA pada tahun 2014 (sesudah akuisisi) mengalami penurunan. Penurunan laba ini dikarenakan perusahaan menegluarkan beban usaha yang tinggi. Hal ini dikarenakan setelah melakukan akuisisi perusahaan masih mengeluarkan biaya untuk membiayai setelah aktivitas akuisisi. Hal ini terjadi karena pihak perusahaan kurang mampu mengoptimalkan penggunaan keseluruhan ekuitas yang bertambah besar sehingga tingkat pengembalian yang diharapkan juga mengalami penurunan secara signifikan. Sehingga, dapat disimpulkan bahwa terdapat perbedaan Return On Equity yang signifikan pada saat sebelum dan sesudah aktivitas akuisisi. Hasil penelitian tersebut konsisten dengan hasil penelitian yang dilakukan oleh Aprilia (2015) yang menyimpulkan terjadi peningkatan return on equity yang signifikan setelah melaksanakan akuisisi.

Return On Assets (ROA) Sebelum dan sesudah akuisisi dan merger.

Hasil penelitian ini mendukung hipotesis ketiga yaitu Return On Assets (ROA) berbeda secara signifikan antara sebelum dan sesudah akuisisi. Data tersebut menunjukkan bahwa terdapat perbedaan signifikan pada Return On Assets sebelum dan setelah akuisisi. Maka hipotesis alternatif ketiga (Ha.3) dalam penelitian ini diterima.

Aktivitas akuisisi tidak membuat kemampuan perusahaan dalam memperoleh laba meningkat. Ratarata return on assets yang relatif mengalami penurunan setelah melakukan aktivitas akuisisi menunjukkan bahwa penggabungan total aktiva perusahaan yang bergabung tidak mampu meningkatkan perolehan laba perusahaan secara signifikan.

Penurunan tersebut ditunjukkan dengan rata-rata ROA sebelum akuisisi sebesar 11,79\%, dan pada saat setelah akuisisi menjadi 5,50\%, sehingga perubahan penurunan rata-rata ROA setelah akuisisi sekitar $53 \%$. Sebagai salah satu contoh perusahaan sampel yaitu ADRO. Total asset yang dimiliki oleh ADRO pada saat setelah melakukan akuisisi mengalami peningkatan, tetapi disisi laba rugi yaitu laba bersih justru mengalami penurunan sehingga menyebabkan Return On Assets cenderung menurun. Berikut adalah ringkasan laporan keuangan yang dimiliki ADRO. 
urnal Akuntansi \& Perpajakan

Vol. 5 (2) 2019: 95-114

\begin{tabular}{|c|c|c|c|c|}
\hline & Notes & 2013 & 2012 & \\
\hline Pendapatan usaha & 30 & $3,285,142$ & $3,722,489$ & Revenue \\
\hline Beban pokok pendapatan & 31 & $(2.545 .956)$ & $(2.679 .867)$ & Cost of revenue \\
\hline Laba bruto & & 739,186 & $1,042,622$ & Gross profit \\
\hline $\begin{array}{l}\text { Beban usaha } \\
\text { Pendapatan/(beban) lain-lain, neto }\end{array}$ & $\begin{array}{l}32 \\
33\end{array}$ & $\begin{array}{r}(173,089) \\
(31,812)\end{array}$ & $\begin{array}{r}(173,067) \\
(33,171)\end{array}$ & $\begin{array}{l}\text { Operating expenses } \\
\text { Other income/(expenses), net }\end{array}$ \\
\hline Laba usaha & & 534,285 & 836,384 & Operating income \\
\hline $\begin{array}{l}\text { Biaya keuangan } \\
\text { Pendapatan keuangan } \\
\text { Bagian atas rugi neto entitas asosiasi }\end{array}$ & 13 & $\begin{array}{c}(116,582) \\
16,139 \\
(14,558)\end{array}$ & $\begin{array}{r}(118,347) \\
11,119 \\
(15,432)\end{array}$ & $\begin{array}{r}\text { Finance costs } \\
\text { Finance income } \\
\text { Share in net loss of associates }\end{array}$ \\
\hline & & $(115,001)$ & $(122.660)$ & \\
\hline Laba sebelum pajak penghasilan & & 419,284 & 713,724 & Profit before income tax \\
\hline Beban pajak penghasilan & $34 d$ & $(190.021)$ & $(330.417)$ & income tax expense \\
\hline Laba tahun berjalan & & 229,263 & 383,307 & Profit for the year \\
\hline
\end{tabular}

Gambar 3. Ringkasan Laporan Keuangan P.T. ADARO Energi

Sumber: www.idx.co.id (2018)

Dari gambar 3 diatas, terlihat bahwa laba bersih yang dimiliki perusahaan mengalami penurunan yang luamayan besar. Hal ini karena pihak perusahaan kurang mampu mengoptimalkan penggunaan keseluruhan aktiva yang bertambah besar sehingga tingkat pengembalian yang diharapkan juga mengalami penurunan secara signifikan. Penurunan laba bersih yang terjadi pada ADRO dikarenakan setelah melakukan akuisisi, nilai penjualan yang dihasilkan oleh ADRO justru mengalami penurunan tetapi nilai beban pokok yang dikeluarkan oleh ADRO sangat besar. Sehingga hal ini menyebabkan laba yang dimiliki ADRO menjadi menurun dan nilai Return On assets mengalami penurunan yang signifikan.

Sehingga, dapat disimpulkan bahwa terdapat perbedaan Return On Assets yang signifikan pada saat sebelum dan sesudah aktivitas akuisisi. Hasil penelitian tersebut konsisten dengan hasil penelitian yang dilakukan oleh Romapurmasari (2011) dan Syafitri (2016) yang menyimpulkan bahwa Return On Assets terdapat perbedaan yang signifikan setelah melaksanakan akuisisi.

Total Assets Turn Over (TATO) sebelum dan sesudah akuisisi

Hasil penelitian ini mendukung hipotesis ketiga yaitu Total Assets Turn Over (TATO) berbeda secara signifikan antara sebelum dan sesudah akuisisi. Data tersebut menunjukkan bahwa terdapat perbedaan signifikan pada Total Assets Turn Over sebelum dan setelah akuisisi. Maka hipotesis alternatif pertama (Ha.4) dalam penelitian ini diterima.

Rata-rata Total assets turn over yang relatif mengalami penurunan setelah melakukan aktivitas akuisisi menunjukkan bahwa penggabungan total aktiva perusahaan yang bergabung tidak mampu meningkatkan perolehan penjualan perusahaan secara signifikan. Nilai rata-rata Total Assets Turnover pada saat sebelum akuisisi sebesar 0,85 kali dan pada saat setelah melakukan akuisisi menjadi 0,73 kali, sehingga penurunan Total Assets Turnover setelah melakukan akuisisi sebesar 14\%. Salah satu perusahaan sampel yang mengalami penurunan pada nilai Total Assets Turnover adalah DPNS. Berikut adalah ringkasan laporan keuangan yang dimiliki DPNS. 


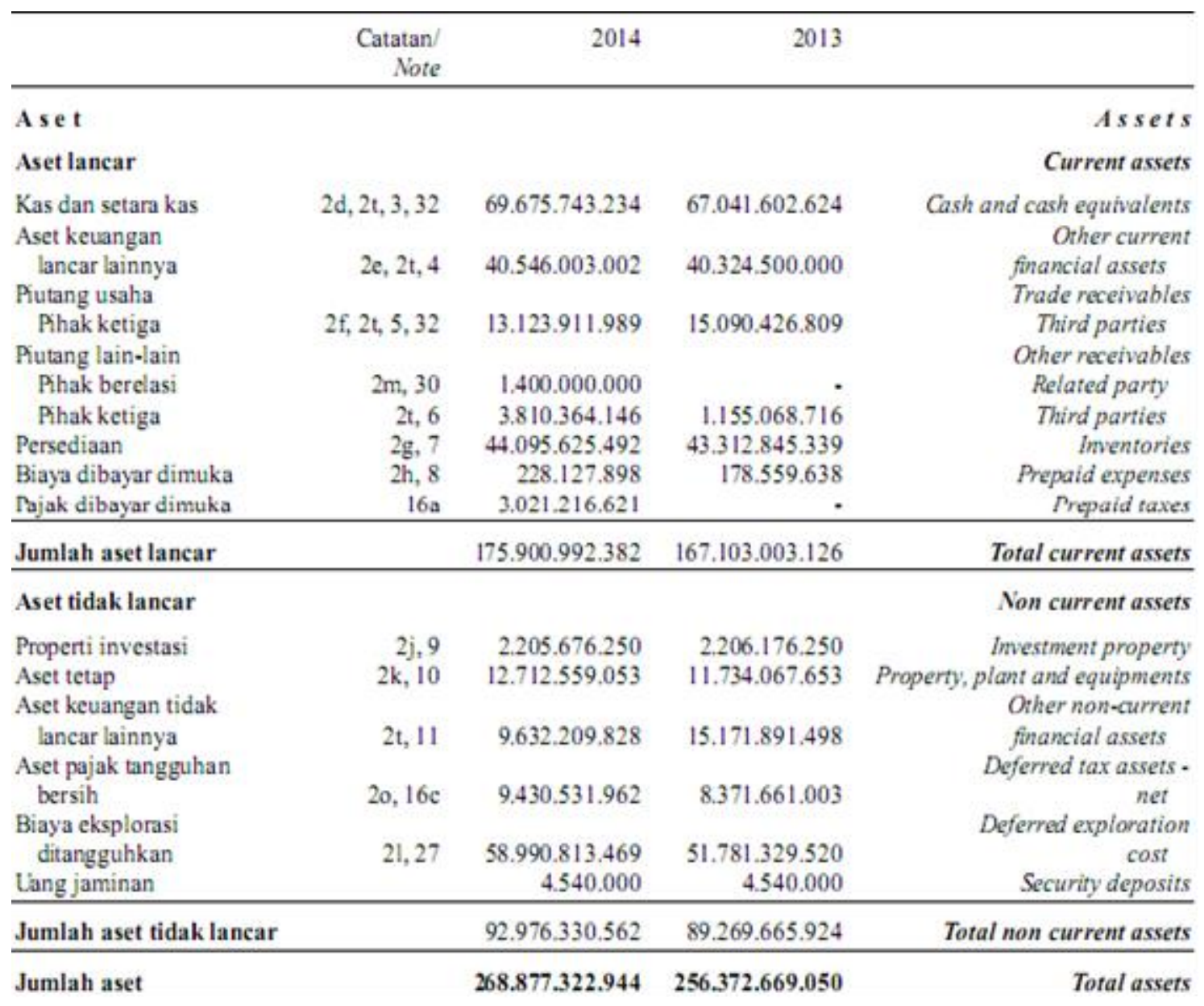

Gambar 4. Ringkasan Laporan keuangan PT Duta Pertiwi Nusantara Tbk

Sumber: www.idx.co.id (2018)

Pada gambar diatas terlihat bahwa jumlah total aset mengalami peningkatan pada saat setelah melakukan akuisisi dengan jumlah penjualan ersih junga mengalami peningkatan. Hal ini mengindikasikan bahwa perusahaan mampu mengalokasikan total asetnya secara efektif untuk meningkatkan jumlah penjualan dalam perusahaan. Perusahaan dirasa cukup mampu dalam mengelola seluruh aktivanya untuk menghasilkan penjualan yang tinggi. Total Assets Turn Over (TATO) dalam penalitian ini menunjukkan adanya penurunan kinerja namun tidak signifikan pada periode 3 tahun sebelum dan sesudah akuisisi. Sehingga, dapat disimpulkan bahwa terdapat perbedaan Total Assets Turn Over yang signifikan pada saat sesudah aktivitas akuisisi. Hasil penelitian tersebut tidak konsisten dengan hasil penelitian yang dilakukan oleh Finansia (2017) dan Aprilia (2015) yang menyimpulkan bahwa tidak terdapat perbedaan yang signifikan pada TATO.

Debt to Equity Ratio (DER) sebelum dan sesudah akuisisi

Hasil penelitian ini mendukung hipotesis kelima yaitu Debt to Equity Ratio (DER) berbeda secara signifikan antara sebelum dan sesudah akuisisi. Data tersebut menunjukkan bahwa tidak terdapat perbedaan yang signifikan pada Debt to Equity Ratio sebelum dan setelah akuisisi. Maka hipotesis alternatif pertama (Ha.5) dalam penelitian ini ditolak.

Aktivitas akuisisi membuat kemampuan perusahaan dalam melunasinutang jangka pendeknya semakin baik. Rata-rata Debt to Equity yang relatif mengalami penurunan setelah melakukan aktivitas akuisisi menunjukkan bahwa penggabungan ekuitas perusahaan yang bergabung mampu melunasi kewajiban perusahaan secara tidak signifikan. Nilai rata-rata Debt to Equity pada saat sebelum akuisisi sebesar 98,24\% sedangkan setelah melakukan akuisisi menjadi 96,56\%, Sehingga penurunan nilai rata-rata Debt to Equity 
Ratio hanya sebesar $2 \%$.

Salah satu perusahaan sampel yang memiliki nilai Debt to Equity Ratio menurun yaitu DPNS. Total Ekuitas yang dimiliki oleh DPNS pada saat setelah melakukan akuisisi mengalami peningkatan, dengan jumlah kewajiban yang mengalami penurunan setelah melakukan akuisisi sehingga menyebabkan Debt to Equity Ratio cenderung menurun. Berikut adalah ringkasan laporan keuangan yang dimiliki oleh DPNS

\begin{tabular}{|c|c|c|c|c|}
\hline & $\begin{array}{r}\text { Catatan/ } \\
\text { Note } \\
\end{array}$ & 2014 & 2013 & \\
\hline Labilitas dan ekuitas & & & & Liabilities and equity \\
\hline Liabilitas jangka pendek & & & & Current liabilities \\
\hline Utang usaha & & & & Trade payables \\
\hline Phak ketiga & $2 t, 12,32$ & 9.502 .282 .511 & 10.200 .943 .412 & Third parties \\
\hline Utang lain-lain & & & & Other payables \\
\hline Pihak ketiga & $2 t, 13$ & 281.789 .900 & 339.781 .575 & Third parties \\
\hline Utang dividen & 14 & 1.303 .731 .287 & 1.244 .979 .505 & Dividend payable \\
\hline Biaya masih harus dibayar & $2 t, 15,32$ & 17.259 .600 & 108.648 .269 & Accrued expenses \\
\hline Utang pajak & $16 \mathrm{~b}$ & 3.157 .001 .281 & 4.407 .021 .774 & Taxes payables \\
\hline Jaminan sewa kantor & 17 & 122.877 .000 & 122.877 .000 & Office rental deposit \\
\hline $\begin{array}{r}\text { Jumlah liabilitas } \\
\text { jangka pendek }\end{array}$ & & 14.384 .941 .579 & 16.424 .251 .535 & $\begin{array}{c}\text { Total current } \\
\text { liabilities } \\
\end{array}$ \\
\hline Liabilitas jangka panjang & & & & Non current liabilites \\
\hline $\begin{array}{l}\text { Kewajiban imbalan } \\
\text { pasca kerja }\end{array}$ & $2 o, 2 t, 18$ & 18.409 .859 .093 & 16.520 .452 .726 & $\begin{array}{c}\text { Post employment benefit } \\
\text { obligation }\end{array}$ \\
\hline $\begin{array}{c}\text { Jumlah liabilitas } \\
\text { jangka panjang }\end{array}$ & & 18.409 .859 .093 & 16.520 .452 .726 & $\begin{array}{c}\text { Total non current } \\
\text { liabilities } \\
\end{array}$ \\
\hline Jumlah liabilitas & & 32.794 .800 .672 & 32.944 .704 .261 & Total liabilities \\
\hline
\end{tabular}

Gambar 5. Ringkasan Laporan Keuangan P.T. Duta Pertiwi Nusantara Tbk. Sumber: www.idx.co.id

Dari gambar diatas terlihat bahwa nilai kewajiban yang dimiliki oleh DPNS mengalami penurunan setelah dilakuknannya penggabungan usaha akuisisi. Hal ini mengindikasikan bahwa perusahaan cukup bisa dikatakan mampu untuk membayar hutang yang dimiliki perusahaan dan mampu untuk memaksimalkan modal sendiri. Berarti modal sendiri sudah cukup untuk menjamin atau melunasi hutang perusahaan karena ekuitas perusahaan lebih tinggi dari pada hutang perusahaan.

Sehingga, dapat disimpulkan bahwa tidak terdapat perbedaan Debt to Equity Ratio yang signifikan pada saat sesudah aktivitas akuisisi dan merger. Hasil penelitian tersebut konsisten dengan hasil penelitian yang dilakukan oleh Aprilia (2015) yang menyimpulkan bahwa tidak terdapat perbedaan yang signifikan pada DER perusahaan sebelum dan setelah akuisisi. Debt to Equity (DER) dalam penalitian ini menunjukkan adanya penurunan kinerja namun tidak signifikan pada periode 3 tahun sebelum dan sesudah akuisisi

Current Ratio (CR) sebelum dan sesudah akuisisi

Hasil penelitian ini mendukung hipotesis kelima yaitu Current Ratio (CR) berbeda secara signifikan antara sebelum dan sesudah akuisisi. Data tersebut menunjukkan bahwa tidak terdapat perbedaan yang signifikan pada Curret Ratio sebelum dan setelah akuisisi. Maka hipotesis alternatif pertama (Ha.6) dalam penelitian ini ditolak.

Terlihat dari perubahan nilai current ratio sebelum dan sesudah akuisisi pada penelitian ini yang relatif kecil. Rata-rata current ratio saat sebelum akuisisi sebesar $223,25 \%$ dan pada saat setelah akuisisi menjadi sebesar $265,27 \%$, nilai rata-rata current ratio hanya meningkat sekitar $19 \%$. Hal tersebut mengindikasikan bahwa tidak terdapat perbedaan kinerja keuangan perusahaan diukur dengan current ratio setelah melakukan akuisisi, dikarenakan kemampuan perusahaan menggunakan aktiva lancar untuk memenuhi kewajiban jangka pendeknya tidak mengalami perbedaan secara signifikan dari sebelum perusahaan melakukan aktivitas akuisisi. Sebagai salah satu contoh dari perusahaan sampel yaitu DPNS 


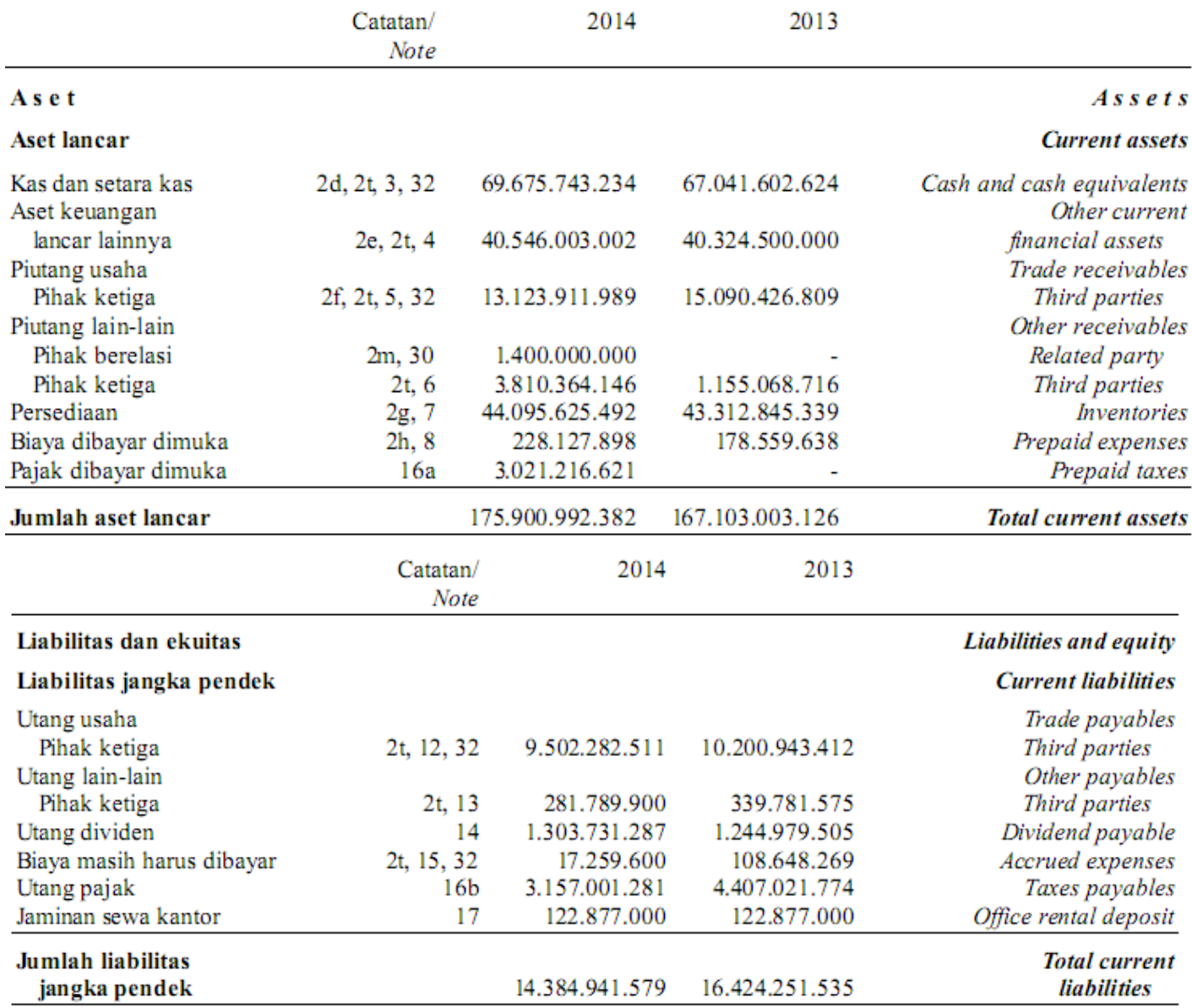

Gambar 6. Ringkasan Laporan Keuangan PT Duta Pertiwi Nusantara Tbk Sumber : www.idx.co.id (2018)

Pada gambar diatas terlihat bahwa komposisi aktiva lancar lebih besar diabnding kewajibanlancar. Aktiva lancar mengalami peningkatan yaitu dikarenakan adanya penggabungan usaha akuisisi, akan tetapi kewajiban lancar justru mengalami penurunan setelah dilakukannya akuisisi. Dengan demikian perusahaan pada saat sesudah melakukan akuisisi dalam kondisi likuid, yang berarti bahwa perusahaan mampu memenuhi kewajiban yang harus segera dipenuhi dalam jangka pendek. Namun kemampuan perusahaan menggunakan aktiva lancar untuk memenuhi kewajiban jangka pendeknya tidak mengalami perbedaan secara signifikan dari sebelum perusahaan melakukan aktivitas akuisisi.

Sehingga, dapat disimpulkan bahwa tidak terdapat perbedaan Current Ratio yang signifikan pada saat sesudah aktivitas akuisisi. Hasil penelitian tersebut konsisten dengan hasil penelitian yang dilakukan oleh Finansia (2017) yang menyimpulkan bahwa tidak terdapat perbedaan yang signifikan pada CR perusahaan sebelum dan setelah akuisisi.

Earning per Share (EPS) sebelum dan sesudah akuisisi

Hasil penelitian ini mendukung hipotesis ketujuh yaitu Earning per Share (EPS) berbeda secara signifikan antara sebelum dan sesudah akuisisi. ata tersebut menunjukkan bahwa terdapat perbedaan signifikan pada Total Assets Turn Over sebelum dan setelah akuisisi. Maka hipotesis alternatif ketiga (Ha.7) dalam penelitian ini diterima.

Aktivitas akuisisi dan merger tidak membuat kemampuan perusahaan dalam memperoleh laba yang dibagikan kepada pemegang saham menurun. Nilai rata-rata Earning per Share pada saat sebelum akuisisi sebesar 289,78 kali sedangkan pada saat setelah akuisisi sebesar 181,74 kali, penurunan rata-rata Earning per Share setelah akuisisi sebesar 37\%. Seperti penurunan Earning per share yang terjadi pada DPNS, dengan jumlah pembagian saham yang tetap untuk setiap tahunnya dengan laba yang mengalami penurunan 
Jurnal Akuntansi \& Perpajakan

Vol. 5 (2) 2019: 95-114

setelah melakukan akuisisi menyebabkan menurunnya nilai Earning per Share.

\begin{tabular}{|c|c|c|c|c|}
\hline & 2014 & $\begin{array}{r}\text { Catatan/ } \\
\text { Note } \\
\end{array}$ & 2013 & \\
\hline Penjualan bersih & 132.775 .925 .237 & $2 n, 23$ & 131.333 .196 .189 & Net sales \\
\hline Beban pokok penjualan & $(98.907 .795 .081)$ & $2 \mathrm{n}, 24$ & $(103.601 .858 .426)$ & Cost of goods sold \\
\hline Laba bruto & 33.868 .130 .156 & & 27.731 .337 .763 & Gross profit \\
\hline $\begin{array}{l}\text { Beban usaha } \\
\text { Pendapatan lain-lain } \\
\text { Pemulihan beban penyisihan } \\
\text { penurunan nilai atas beban } \\
\text { eksplorasi \& pengembangan } \\
\text { Beban lain-lain }\end{array}$ & $\begin{array}{c}(24.929 .367 .345) \\
8.321 .469 .656\end{array}$ & $\begin{array}{r}2 \mathrm{n}, 25 \\
26\end{array}$ & $\begin{array}{c}(23.872 .233 .545) \\
8.822 .675 .706\end{array}$ & $\begin{array}{r}\text { Operating expenses } \\
\text { Other income } \\
\text { Restitution for provision } \\
\text { in value of the exploration } \\
\text { and development expense } \\
\text { Other expenses }\end{array}$ \\
\hline Laba usaha & 17.183 .018 .745 & & 42.636 .885 .085 & Profit from operations \\
\hline $\begin{array}{l}\text { Laba penjualan saham } \\
\text { entitas asosiasi } \\
\text { Bagian laba (rugi) bersih } \\
\text { dari entitas asosiasi } \\
\end{array}$ & $\cdot$ & & $\begin{array}{r}44.269 .891 .310 \\
416.054 .066 \\
\end{array}$ & $\begin{array}{l}\text { Gain on sales of share } \\
\text { of associated company } \\
\text { Net portion of gain (loss) of } \\
\text { associated company }\end{array}$ \\
\hline $\begin{array}{l}\text { Laba sebelum } \\
\text { pajak penghasilan }\end{array}$ & 17.183 .018 .745 & & 87.322 .830 .461 & $\begin{array}{r}\text { Profit before } \\
\text { income tax } \\
\end{array}$ \\
\hline $\begin{array}{l}\text { Penghasilan (beban) pajak : } \\
\text { Pajak kini } \\
\text { Pajak tangguhan }\end{array}$ & $\begin{array}{c}(3.974 .453 .500) \\
1.311 .301 .039 \\
\end{array}$ & $\begin{array}{l}2 \mathrm{p}, 16 \mathrm{~b} \\
2 \mathrm{p}, 16 \mathrm{c}\end{array}$ & $\begin{array}{r}(6.613 .783 .500) \\
(13.895 .816 .640) \\
\end{array}$ & $\begin{array}{c}\text { Tax income (expense) : } \\
\text { Current tax } \\
\text { Deferred tax } \\
\end{array}$ \\
\hline $\begin{array}{l}\text { Jumlah penghasilan } \\
\text { (beban) pajak }\end{array}$ & $(2.663 .152 .461)$ & & $(20.509 .600 .140)$ & $\begin{array}{c}\text { Total tax } \\
\text { income (expense) } \\
\end{array}$ \\
\hline Laba tahun berjalan & 14.519 .866 .284 & & 66.813 .230 .321 & Profit for the year \\
\hline
\end{tabular}

Gambar 7. Ringkasan Laporan Keuangan PT Duta Pertiwi Nusantara Tbk

Sumber: www.idx.co.id (2018)

Penurunan yang terjadi ini diakarenakan setelah perusahaan melakukan akuisisi, terjadi penurunan pada laba yang dibagikan ke pemegang saham. Pada saat setelah melakukan akuisisi DPNS mengeluarkan biaya operasional yang cukup besar dibandingkan pada saat sebelum akuisisi, sehingga hal ini menyebabkan laba yang dihasilkan mengalami penurunan. Biaya yang dikeluarkan oleh perusahaan ini, digunakan untuk membiayai kegiatan usaha perusahaan setelah adanya penggabungan usaha. Sehingga, dapat disimpulkan bahwa terdapat perbedaan Earning Per Share yang signifikan pada saat sesudah aktivitas akuisisi. Hasil penelitian tersebut konsisten dengan hasil penelitian yang dilakukan oleh Aprilia (2015) yang menyimpulkan bahwa terdapat perbedaan yang signifikan pada EPS perusahaan sebelum dan setelah akuisisi.

\section{SIMPULAN DAN SARAN}

Dapat diambil kesimpulan bahwa terdapat perbedaan penurunan yang signifikan pada Net Profit Margin (NPM), Return On Equity (ROE), dan Return On Assets (ROA), sebelum dan setelah melakukan akusisi. Akan tetapi terdapat perbedaan peningkatan yang tidak signifikan pada Total Assets Turn Over (TATO ) dan Current Ratio (CR) sebelum dan setelah melakukan akusisi. Selain itu terdapat perbedaan penurunan yang tidak signifikan pada Debt to Equity Ratio (DER) dan Earning Per Share (EPS) pada sebelum dan setelah melakukan akusisi.

Beberapa saran yang dapat peneliti sampaikan berdasarkan penelitian yang telah dilakukan adalah bagi peneliti selanjutnya yang menggunakan penelitian yang sama disarankan untuk dapat menambah jumlah sampel dengan memperpanjang periode pengamatan penelitian sehingga data yang diolah lebih mewakilkan perbedaan yang didapat setelah perusahaan memutuskan untuk bergabung dengan perusahaan lain. Penelitian selanjutnya diharapkan untuk menambahkan variabel-variabel lain yang dapat digunakan untuk mengukur perbedaan kinerja keuangan perusahaan sebelum dan setelah akuisisi dan merger. Selain itu penelitian selanjutnya diharapkan dapat memisahkan uji analisis data yakni mengumpulkan serta menganalisis data perusahaan yang melakukan merger atau akuisisi secara terpisah. 


\section{DAFTAR PUSTAKA}

Aprilita Ira, (2013). Analisis Perbandingan Kinerja Keuangan Perusahaan Sebelum dan Sesudah Akuisisi (Study Pada Perusahaan Pengakuisisian Yang Terdaftar di BEI Periode 2000-2011). Jurnal Mnajemen dan Bisnis Sriwijaya Vol.11 No.2 Juni 2013.

Aprilia, Nur Sylvia, (2015), Perbandingan Kinerja Keuangan Sebelum Dan SesudahAkuisisi Pada Perusahaan Manufaktur, Jurnal Ilmu Dan Riset Manajemen Volume 4, Nomor 12, Desember 2015, Sekolah Tinggi Ilmu Ekonomi Indonesia (STIESIA) Surabaya

Bagus Yanuar, (2009). Analisis Pengaruh Akuisisi Terhadap Kinerja Perusahaan (Studi Empiris Pada Pt. Sampoerna Tbk Di Bursa Efek Indonesia). Fakultas Ekonomi. Universitas Muhammadiyah Surakarta.

Baker. Richard E. et al. (2015). Perspektif Indonesia Akuntansi Keuangan Lanjutan. Edisi 2 buku 1. Salemba Empat. Yogyakarta.

Bayuristyawan, Tito. (2013). Analisis Manajemen Laba dan Kinerja Keuangan Perusahaan Pengakuisisi Sebelum dan Sesudah Merger dan Akuisisi yang Terdaftar di Bursa Efek Indonesia Tahun 20102011. Jurnal Akuntansi Fakultas. Universitas Muhammadiyah Surakarta.

Dewi, Sevika Ranita. (2015). Analisa Perbandingan Kinerja Keuangan BeberapaPerusahaan Sebelum dan Sesudah Akuisisi (Studi Pada Perusahaan Pengakuisisi yang Terdaftar di BEI Periode 2003-2013). Jurnal Ekonomi dan Bisnis. Universitas Dian Nuswantoro

Finansia Linda. (2017). Analisis Kinerja Keuangan Perusahaan Sebelum Dan Setelah Merger Dan Akuisisi. Skripsi. Fakultas Ekonomi Universitas Negeri Yogyakarta.

Fitriasari Faranita. (2016). Analisis Perbandingan Kinerja Keuangan Perusahaan Sebelum Dan Sesudah Merger Dan Akuisisi Terhadap Manajemen Entrenchment (Studi Perusahaan Yang Melakukan Merger Dan Akuisisi yang Terdaftar Di BEI Periode 2011-2013). Skripsi. Fakultas Ekonomi Dan Bisnis. Universitas Muhammadiyah Sidoarjo.

Hadi Kuncoro, (2014). Analisis Pengaruh Merger Dan Akuisisi Terhadap Kinerja Keuangan Perusahaan (Studi Kasus Pada Perusahaan Yang Terdaftar Di Bursa Efek Indonesia Periode 2004-2013). Skripsi. Fakultas Ekonomika Dan Bisnis, Universitas Diponegoro.

IAI. (2015). Standar Akuntansi Keuangan Per Efektif 1 Januari 2015.

Hendra Kadek, Sukartha Made, (2013). Kinerja Pasar Dan Kinerja Keuangan Sesudah Merger Dan Akuisisi Di Bursa Efek Indonesia. E-Jurnal Akuntansi Universitas Udayana 5.2 (2013): 271-290.Universitas Udayana.

Mardiyanto, Handono. (2009). Inti Sari Manajemen Keuangan. PT Gramedia Widiasarana Indonesia. Jakarta.

Masithoh Rina, 2015. Dampak Akuisisi Terhadap Kinerja Keuangan Perusahaan.Jurnal Ekonomi Manajemen Vol. 10 No. 1, Januari 2016. Universitas 17 Agustus 1945 Samarinda.

Nugroho, Muhammad Aji. (2010). Analisis Perbandingan Kinerja Keuangan Perusahaan Sebelum dan Sesudah Merger dan Akuisisi (Pada Perusahaan Pengakuisisi, periode 2002-2003). Skripsi. Fakultas Ekonomi. Universitas Diponegoro.

Novaliza Putri, (2013), Analisis Pengaruh Merger Dan Akuisisi Terhadapkinerja Perusahaan Publik Di Indonesia(Periode 2004 - 2011), Jurnal Akuntansi E Bisnis, Vol. 1 No. 1 September 2013Perbanas Institute

Sihombing Neddy, Mustafa Kamal, (2015), Analisis Pengaruh Pengumuman Merger Dan Akuisisi TerhadapAbnormal Return Saham Dan Kinerja Keuangan Perusahaan (Studi Pada Perusahaan Yang Melakukan Merger Dan AkuisisiPada Tahun 2011 Dan Terdaftar Di Bursa Efek Indonesia), Jurnal Manajemen Volume 5, Nomor 3, Tahun 2016, Halaman 1-15, Universitas Diponegoro

Sudana, I made, (2015). Teori dan Praktik Manajemen Keuangan Perusahaan. Edisi 2. Erlangga. Jakarta.

Syafitri Nurul, (2016). Analisis Perbedaan Kinerja KeuanganSebelum Dan Setelah Akuisisi Dan MergerPada Pt. Xl Axiata, Tbk, Skripsi Universitas Gunadarma 2016 Jakarta

www.idx.co.id (Diakses pada tanggal 15 November 2017).

www.sahamok.co.id (Diakses pada tanggal 05 November 2017). 